\title{
Species Diversity and Community Structure of Arthropod Pests and Predators in Flax, Linum Usitatissimum L. from Darjeeling (India)
}

\author{
Suprakash Pal ${ }^{1}$, Rupsanatan Mandal ${ }^{1}$, Indrajit Sarkar ${ }^{1}$, Tulsi Saran Ghimiray ${ }^{1}$, Binay \\ Raj Sharma ${ }^{1}$, Ayon Roy ${ }^{1}$, Suvendu Kumar Roy ${ }^{1}$, Gautam Chakraboorty ${ }^{2}$, Sabyasachi \\ Mitra ${ }^{3}$. \\ ${ }^{1}$ Uttar Banga Krishi Viswavidyalaya - Faculty of Agriculture, Pundibari, West Bengal, India; ${ }^{2}$ Bidhan Chandra \\ Krishi Viswa Vidyalaya, Nadia, West Bengal, India; ${ }^{3}$ Central Research Institute for Jute and Allied Fibres - AINP \\ on Jute and Allied Fibres, Barrackpore, West Bengal, India.
}

\begin{abstract}
The species richness and relative abundances of different aboveground plant-dwelling pest and predator species were assessed in flax (Linum usitatissimum L.) ecosystem under mid-hill conditions of eastern Himalayas. The experiment was conducted in winter seasons during 2004-2013 at the Regional Research Station (Hill Zone), Uttar Banga Krishi Viswavidyalaya, Kalimpong, West Bengal, India. Twenty five species of phytophagous arthropods under 13 families were observed belonging to 6 different orders. The gram pod borer, Helicoverpa armigera (Noctuidae: Lepidoptera), aphid, Myzus persicae (Aphididae: Hemiptera), shield bug, Plautia fimbriata (Pentatomidae: Hemiptera) and leaf webber, Nacoleia sp. (Pyralidae: Lepidoptera) were found as the most common and major insect of flax. In terms of species composition, Hemiptera and Lepidoptera occupied top position (nine species) while Coleoptera ranked second position (five species). By the size of population, aphid was found to be the most frequent species followed by shield bug and leaf webber. Although, the incidence of gram pod borer was low in the field, it was the major pest of flax in respect of bud and capsule damage. The Gini-Simpson index and Effective number of species for the pest faunal complex of flax was calculated as 0.914 and 11.628, respectively. Similarly, 16 species of predatory arthropods under nine families were observed belonging to 7 different orders. The lynx spider (17.24 \%) and 7-spotted lady beetle $(15.52 \%)$ dominated the predatory community by sheer number. The GiniSimpson index and Effective number of species for the predatory fauna was derived as 0.898 and 9.804, respectively.
\end{abstract}

Key words: Flax, pests, predators, species richness, abundance

\footnotetext{
*Author for correspondence: palsento@gmail.com
} 


\section{INTRODUCTION}

Flax (Linum usitatissimum L.) is an oilseed and fibre crop $\left[{ }^{1}\right]$ that belongs to the family Linaceae. Flax is believed to have originated in Mediterranean regions and/or South-west Asia $\left[{ }^{2}\right]$. Oilseed varieties and fibre varieties are specialized development of this species. The cultivars grown for fibre purpose are tall growing with straight culms and have fewer secondary branches. Flax is a source of industrial fibres and, presently, flax fibres have become an important part of new composite materials utilized in automobile and constructive industries. It is a cool season crop and grows well during winter season in the mid-hill conditions of West Bengal, India.

Arthropods are important components of ecosystems occupying vital positions in food webs, dynamics of populations and communities. They play various roles in ecosystems acting as herbivores, predators, decomposers, parasitoids and pollinators $\left[{ }^{3}\right]$. The knowledge of population ecology of arthropods in an agro-ecosystem is of utmost importance for a clear understanding of the numerous relationships between crop plants, insects and natural enemies. The information regarding the diversity of arthropod in a particular agroecological condition is very much important for formulating suitable pest management strategies. Arthropods because of their small size, diversity and sensitivity to environmental variability, can be good indicators of habitat heterogeneity, ecosystem biodiversity, and environmental stress $\left[{ }^{4}\right]$.

Population ecologist discussed diversity of arthropods in two aspects, the number of species present (i.e. species richness) and their relative abundance (i.e. dominance or evenness). The species diversity and their relative abundance in a community are measured mathematically by a number of diversity indices. Therefore, diversity indices provide more information about community composition than simply species richness; they also take the relative abundances of different species into account. Diversity indices provide important information about rarity and commonness of species in a community. The ability to quantify diversity in this way is an important tool for biologists trying to understand community structure. But, entropies such as the Shannon-Wiener and Gini-Simpson indices are not themselves diversities. Conversion of these indices to effective number of species is the key to a unified and intuitive interpretation of diversity $\left[{ }^{5}\right]$.

The diversity of pests and predators in flax has earlier been studied by Deshmukh et al. $\left[{ }^{6}\right]$, Malik $[7]$, Prasad and Prasad $\left[^{8}\right]$ and Mishra and Ali $\left[{ }^{9}\right]$ under varied agroclimatic conditions of India. However, such information with respect to flax agroecosystem is very much scanty particularly from hill zone of West Bengal. Keeping this point in view, the present investigation was undertaken to study the species diversity and community composition of aboveground plant-dwelling arthropod pests and predators in flax under agro-climatic conditions of Darjeeling hills.

\section{MATERIALS AND METHODS}

\section{Study area}

The experiment was carried out at Kalimpong $\left(27^{\circ} 04^{\prime} \mathrm{N}\right.$ latitude and $88^{\circ} 35^{\prime} \mathrm{E}$ longitude at an elevation of 1250 meter above the MSL) that lies in the northern part of West Bengal (India) in the mid-hills of eastern Himalayas. The average maximum and minimum temperature round the year recorded $20^{\circ} \mathrm{C}$ and $2^{\circ} \mathrm{C}$ respectively. The relative humidity varies from 70 to $80 \%$ depending upon the season. The average rainfall varies from 2500 to $3000 \mathrm{~mm}$, of which $80 \%$ is received during June to September. The farm where the experiment was conducted is situated in the hilly terraces with a comparatively heterogeneous landscape pattern. More heterogeneous 
landscapes contain many different production cover types (e.g. different field crops, intensively grazed lands, orchards) which are distributed in a complex pattern and interspersed with other, more 'natural', cover types (e.g. extensively grazed or nongrazed woodlands, wetlands, field margins). Such patterns are characteristic of traditional farming systems, in contrast with intensive agricultural systems which typically contain only a few sown crop types distributed in large uniform fields $\left[{ }^{10}\right]$.

\section{Sampling technique and data collection}

The number of species was the simplest measure of species diversity. The counting of aboveground arthropod pests and predators were done by one absolute method viz., visual searching and one relative method viz., using sweep net. The jassid, aphid and thrips population were counted from a random sample of 5 plants taken from each plot. Three leaves were chosen randomly on each plant, selecting one leaf each from top, middle and bottom portion of plant. The lower surface of leaf was thoroughly examined for the presence of any insect $[3,11,12]$. The data were pooled over the season and season's average was combined to provide an overall average density per plot. The population of beetles, large sized bugs, grasshoppers and spiders were counted from 3 branches selected randomly from 5 plants each plot. Sweeping method was used for counting flying insects. Five times sweeping was done in each plot to make a composite sample. Each sample was examined separately without killing the insects and released them in the same plot immediately after counting.

\section{Identification}

The coreid and pentatomid bugs were identified by Dr. Animesh Bal, Hemiptera section, ZSI, Kolkata. Thanks are due to the In-charge, C.E.L. section for identifying the coccinellid beetles.

\section{Statistical Analysis}

The Gini-Simpson index $\left[{ }^{13}\right]$ and Effective number of species $\left[{ }^{5}\right]$ were applied to understand the community composition of pests and predators.

So, Gini-Simpson index $(\mathrm{x})=1-\sum_{\mathrm{i}=1}^{\mathrm{S}} \mathrm{p}_{\mathrm{i}}^{2}$

Where, $\mathrm{p}$ is the proportion $(\mathrm{n} / \mathrm{N})$ of individuals of one particular species found (n) divided by the total number of individuals found $(\mathrm{N}), \sum$ is the sum of the calculations and $\mathrm{s}$ is the total number of insect species found in the community (i.e., the richness).

But, Gini-Simpson index is not itself diversity, it has to be converted to effective numbers of species before it can be treated as true diversity $\left[{ }^{5}\right]$. The number of equally-common species required to give a particular value of an index is called the "effective number of species".

i.e. Effective number of species $=1 /(1-\mathrm{x})$

Where, $\mathrm{x}$ is the Gini-Simpson index.

\section{RESULTS}

\section{Herbivores community}

Twenty five species of herbivores belonging to 13 different families under 6 orders were recorded from the flax ecosystem (Table 1). Nine species of insect pests were found to infest the reproductive parts of plants (flower buds and fruits), nine species were recorded on the stem, and twenty four insect pests were found to damage the foliage. Most of the insect pests belonged to three orders such as Hemiptera, 
Lepidoptera and Coleoptera. In terms of species composition Hemiptera and Lepidoptera occupied top position (9 species) while Coleoptera ranked second position (5 species).

Table 1: List of insect pests observed in the flax ecosystem and their relative abundance

\begin{tabular}{|c|c|c|c|c|c|}
\hline Order & Family & $\begin{array}{l}\text { Common } \\
\text { name }\end{array}$ & Scientific name & $\begin{array}{l}\text { Plant part } \\
\text { harboured }\end{array}$ & $\begin{array}{l}\text { Population } \\
\text { Frequency } \\
(\%)\end{array}$ \\
\hline \multirow[t]{9}{*}{ Hemiptera } & Aphididae & $\begin{array}{l}\text { Green peach } \\
\text { aphid }\end{array}$ & $\begin{array}{l}\text { Myzus persicae } \\
\text { Sulzer }\end{array}$ & $\begin{array}{l}\text { Leaf, stem and } \\
\text { flower bud }\end{array}$ & 15.77 \\
\hline & Cicadellidae & $\begin{array}{l}\text { Green leaf } \\
\text { hopper }\end{array}$ & $\begin{array}{l}\text { Empoasca kerri } \\
\text { Pruthi }\end{array}$ & Leaf & 0.77 \\
\hline & Tingidae & Lace wing bug & Unspecified & Leaf and stem & 2.31 \\
\hline & Pentatomidae & Shield bug & $\begin{array}{l}\text { Plautia fimbriata } \\
\text { (Fabricius) }\end{array}$ & $\begin{array}{l}\text { Leaf, stem and } \\
\text { capsule }\end{array}$ & 15.38 \\
\hline & Pentatomidae & Green stink bug & $\begin{array}{l}\text { Nezara viridula } \\
\text { (Linnaeus) }\end{array}$ & $\begin{array}{l}\text { Leaf, stem and } \\
\text { capsule }\end{array}$ & 1.54 \\
\hline & Pentatomidae & Shield bug & $\begin{array}{l}\text { Dolychoris } \\
\text { baccarum } \\
\text { Linnaeus }\end{array}$ & $\begin{array}{l}\text { Leaf, stem and } \\
\text { capsule }\end{array}$ & 1.15 \\
\hline & Pentatomidae & Shield bug & Dolychoris sp. & $\begin{array}{l}\text { Leaf, stem and } \\
\text { capsule }\end{array}$ & 3.46 \\
\hline & Coreidae & Coreid bug & Cletus punctulatus & $\begin{array}{l}\text { Leaf, stem and } \\
\text { capsule }\end{array}$ & 0.38 \\
\hline & Coreidae & Coreid bug & Cletus sp. & $\begin{array}{l}\text { Leaf, stem and } \\
\text { capsule }\end{array}$ & 0.38 \\
\hline \multirow[t]{5}{*}{ Coleoptera } & Chrysomelidae & $\begin{array}{l}\text { Steel blue } \\
\text { beetle }\end{array}$ & Altica sp. & Leaf & 1.54 \\
\hline & Chrysomelidae & Flea beetle & $\begin{array}{l}\text { Phyllotreta } \\
\text { cruciferae (Goeze) }\end{array}$ & Leaf & 5.00 \\
\hline & Chrysomelidae & Flea beetle & $\begin{array}{l}\text { Phyllotreta } \\
\text { striolata } \\
\text { (Fabricius) }\end{array}$ & Leaf & 8.85 \\
\hline & Chrysomelidae & $\begin{array}{l}\text { White spotted } \\
\text { flea beetle }\end{array}$ & $\begin{array}{l}\text { Monolepta signata } \\
\text { Oliver }\end{array}$ & Leaf & 1.15 \\
\hline & Chrysomelidae & $\begin{array}{l}\text { Red pumpkin } \\
\text { beetle }\end{array}$ & $\begin{array}{l}\text { Aulacophora } \\
\text { foveicollis (Lucas) }\end{array}$ & Leaf & 0.38 \\
\hline \multirow[t]{7}{*}{ Lepidoptera } & Pyralidae & Leaf webber & Nacoleia $\mathrm{sp}$ & Leaf & 10.38 \\
\hline & Noctuidae & $\begin{array}{l}\text { Green } \\
\text { semilooper }\end{array}$ & $\begin{array}{l}\text { Plusia orichalcea } \\
\text { (Fabricius) }\end{array}$ & Leaf & 4.62 \\
\hline & Noctuidae & $\begin{array}{l}\text { Black } \\
\text { semilooper }\end{array}$ & $\begin{array}{l}\text { Grammodes } \\
\text { stolida Fabricius }\end{array}$ & Leaf & 5.38 \\
\hline & Lymantriidae & $\begin{array}{l}\text { Hairy } \\
\text { caterpillar }\end{array}$ & $\begin{array}{l}\text { Euproctis } \\
\text { scintillans Walker }\end{array}$ & Leaf & 0.38 \\
\hline & Noctuidae & Gram pod borer & $\begin{array}{l}\text { Helicoverpa } \\
\text { armigera } \\
\text { (Hubner) }\end{array}$ & Capsule & 2.31 \\
\hline & Noctuidae & $\begin{array}{l}\text { Tobacco } \\
\text { caterpillar }\end{array}$ & $\begin{array}{l}\text { Spodoptera litura } \\
\text { (Fabricius) }\end{array}$ & Leaf & 0.38 \\
\hline & Noctuidae & Cutworm & Agrotis sp. & Stem & 0.38 \\
\hline \multirow[t]{2}{*}{ Diptera } & Agromyzidae & Pea leaf miner & $\begin{array}{l}\text { Phytomyza } \\
\text { horticola Goureau }\end{array}$ & Leaf & 5.00 \\
\hline & Cecidomyiidae & Bud fly & $\begin{array}{l}\text { Dasineura lini } \\
\text { Barnes }\end{array}$ & Flower bud & 0.77 \\
\hline Orthoptera & Acrididae & $\begin{array}{l}\text { Surface } \\
\text { grasshopper }\end{array}$ & Atractomorpha sp. & Leaf & 7.69 \\
\hline Thysanoptera & Thripidae & Thrips & Unspecified & Leaf & 4.62 \\
\hline
\end{tabular}


The data (Table 1) also revealed the relative abundance of different insect pests in flax agroecosystem. It was recorded that the relative abundance (herbivores) of hemiptera, lepidoptera, coleoptera, orthoptera, diptera and thysanoptera were 41.14, 23.83, 16.92, 7.69, 5.77 and 4.62 per cent respectively (Figure 1). Aphid (Myzus persicae Sulzer) was ranked first with respect to the frequency followed by shield bug (Plautia fimbriata Fabricius), leaf webber (Nacoleia sp.) and flea beetle (Phyllotreta striolata Fabricius). The aphid (Myzus persicae Sulzer) and shield bug (Plautia fimbriata Fabricius) consisted of 15.77 and 15.38 per cent of the total population in the flax aboveground herbivores community. Therefore, by number, the sucking insects such as aphid and shield bug occupied the top position in the flax agroecosystem. The population frequency of leaf webber (Nacoleia sp.) and flea beetle (Phyllotreta striolata Fabricius) was 10.38 and 8.85 per cent, respectively. Although the frequency of adult gram pod borer (Helicoverpa armigera Hubner) was very low $(2.31 \%)$ in the field, it was the major pest of flax in respect of capsule damage. The number of adult gram pod borer was very low due to nocturnal in habit and no trap was used to collect the adult at night. Next to gram pod borer, aphid, shield bug and leaf webber were the important pests of flax.

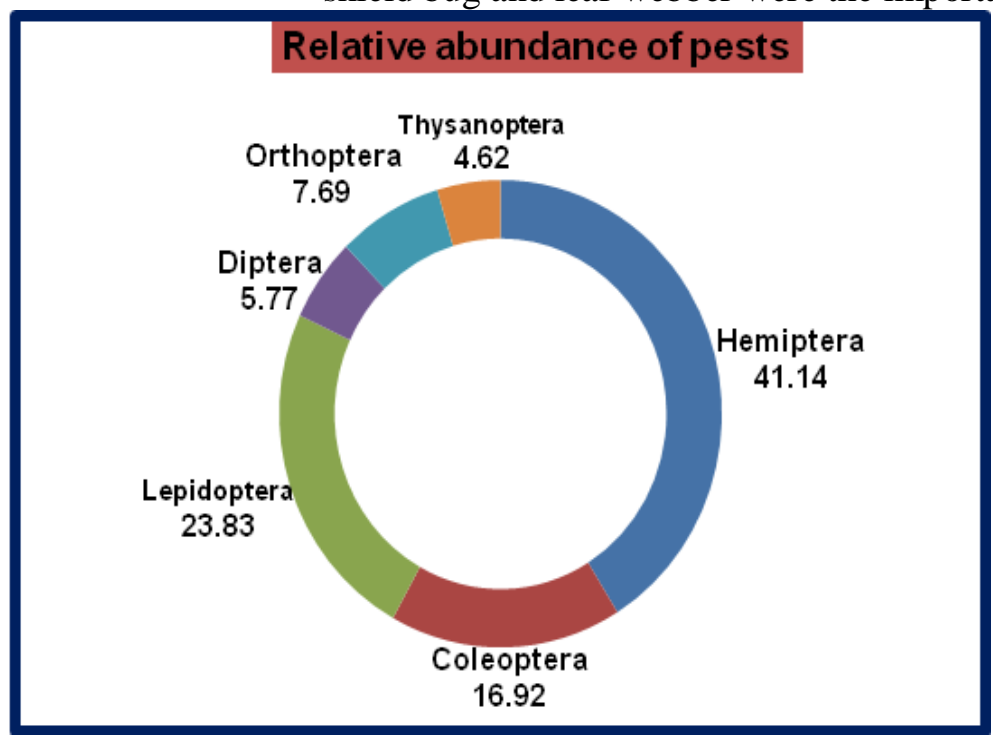

Figure 1: Relative abundance (\%) of herbivorous arthropods in the flax ecosystem

\section{Predaceous community}

The predaceous arthropods in the flax ecosystem were grouped in 9 families under 7 taxonomical orders (Table 2). In total sixteen species of aboveground predatory arthropods were observed in the flax ecosystem. The relative abundance of different predators has been presented in the figure 2 . Mainly spiders $(37.92 \%)$ and lady bird beetles $(37.91 \%)$ constituted the aboveground predatory fauna in the flax ecosystem. The lynx spider, Oxyopes sp. (17.24 \%) dominated the flax ecosystem when population frequency is considered followed by the 7-spotted lady beetle, Coccinella septempunctata $(15.52 \%)$. The rest of the predaceous insects belonged to the order Orthoptera, Dictyoptera, Hymenoptera, Hemiptera and Odonata. 


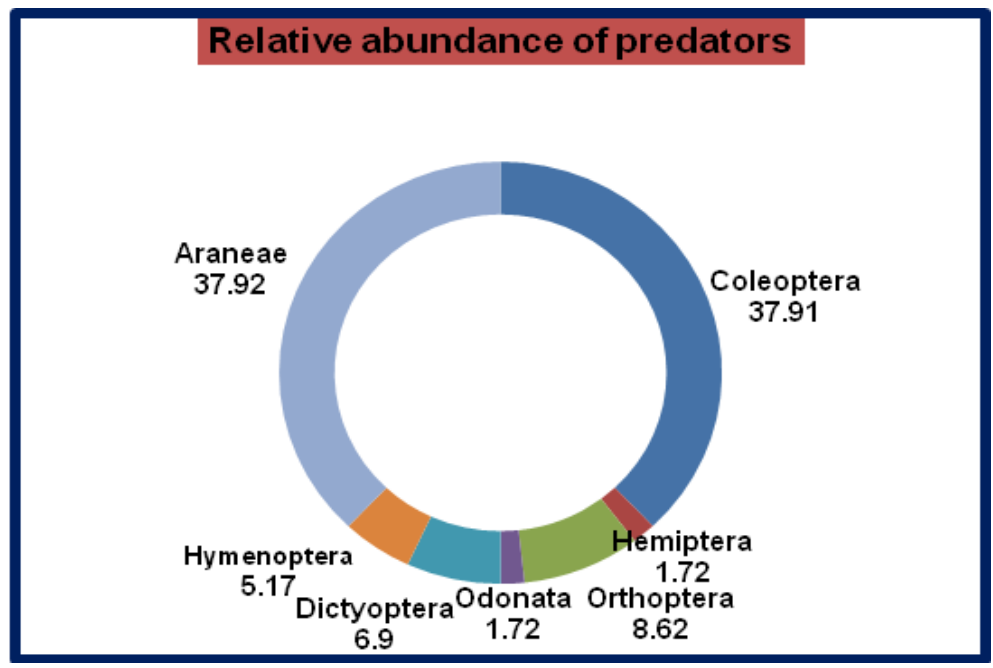

Figure 2: Relative abundance (\%) of predaceous arthropods in the flax ecosystem

Table 2: List of predaceous arthropods observed in the flax ecosystem and their relative abundance

\begin{tabular}{|c|c|c|c|c|c|}
\hline Order & Family & $\begin{array}{l}\text { Common } \\
\text { name }\end{array}$ & Scientific name & $\begin{array}{l}\text { Stage } \\
\text { observed }\end{array}$ & $\begin{array}{l}\text { Population } \\
\text { Frequency } \\
(\%)\end{array}$ \\
\hline \multirow[t]{8}{*}{ Coleoptera } & Coccinellidae & $\begin{array}{l}\text { Lady } \\
\text { beetle }\end{array}$ & $\begin{array}{l}\text { Coelophora } \\
\text { sexareata Mulsant }\end{array}$ & Adult & 5.17 \\
\hline & Coccinellidae & $\begin{array}{l}\text { Lady } \\
\text { beetle }\end{array}$ & $\begin{array}{l}\text { Coccinella } \\
\text { transversalis } \\
\text { Fabricius }\end{array}$ & $\begin{array}{l}\text { Larva } \\
\text { adult }\end{array}$ & 1.72 \\
\hline & Coccinellidae & $\begin{array}{l}\text { Lady } \\
\text { beetle }\end{array}$ & $\begin{array}{l}\text { Coccinella } \\
\text { septempunctata } \\
\text { Linnaeus }\end{array}$ & $\begin{array}{l}\text { Larva } \\
\text { adult }\end{array}$ & 15.52 \\
\hline & Coccinellidae & $\begin{array}{l}\text { Lady } \\
\text { beetle }\end{array}$ & $\begin{array}{l}\text { Oenopia kirbyi } \\
\text { Mulsant }\end{array}$ & Adult & 8.62 \\
\hline & Coccinellidae & $\begin{array}{l}\text { Lady } \\
\text { beetle }\end{array}$ & $\begin{array}{l}\text { Oenopia sauzeti } \\
\text { Mulsant }\end{array}$ & Adult & 1.72 \\
\hline & Coccinellidae & $\begin{array}{l}\text { Lady } \\
\text { beetle }\end{array}$ & $\begin{array}{l}\text { Coelophora } \\
\text { unicolor } \\
\text { (Fabricius) }\end{array}$ & Adult & 1.72 \\
\hline & Coccinellidae & $\begin{array}{l}\text { Lady } \\
\text { beetle }\end{array}$ & $\begin{array}{l}\text { Micraspis discolor } \\
\text { (Fabricius) }\end{array}$ & $\begin{array}{l}\text { Larva } \\
\text { adult }\end{array}$ & 1.72 \\
\hline & Coccinellidae & $\begin{array}{ll}\text { Lady } & \text { bird } \\
\text { beetle } & \end{array}$ & $\begin{array}{ll}\text { Illeis } & \text { sp. } \\
\text { (Fabricius) } & \end{array}$ & Adult & 1.72 \\
\hline Hemiptera & Pentatomidae & $\begin{array}{l}\text { Brown stink } \\
\text { bug }\end{array}$ & $\begin{array}{l}\text { Andrallus } \\
\text { spinidens } \\
\text { Fabricius }\end{array}$ & Adult & 1.72 \\
\hline Orthoptera & Tettigonidae & $\begin{array}{l}\text { Long horned } \\
\text { grasshopper }\end{array}$ & $\begin{array}{l}\text { Conocephalus } \\
\text { longipennis (de } \\
\text { Haan) }\end{array}$ & Adult & 8.62 \\
\hline Odonata & Libellulidae & Dragonfly & Crocothemis sp. & Adult & 1.72 \\
\hline Dictyoptera & Mantidae & Praying mantis & Mantis sp. & Adult & 6.90 \\
\hline Hymenoptera & Formicidae & Fire ant & $\begin{array}{l}\text { Solenopsis } \\
\text { geminata } \\
\text { Fabricius }\end{array}$ & Adult & 5.17 \\
\hline \multirow[t]{3}{*}{ Araneae } & Oxyopidae & Lynx spider & Oxyopes sp. & Adult & 17.24 \\
\hline & Tetragnathidae & $\begin{array}{l}\text { Long jawed } \\
\text { spider }\end{array}$ & Tetragnatha sp. & Adult & 10.34 \\
\hline & Lycosidae & Wolf spider & Pardosa sp. & Adult & 10.34 \\
\hline
\end{tabular}




\section{Diversity index}

The Gini-Simpson index and Effective number of species for the pest faunal complex of flax was calculated as 0.914 and 11.628 , respectively. This means that, according to the Gini-Simpson index, the herbivorous arthropod community of flax ecosystem has the same diversity as a community with $11.628 \approx 12$ equally-common species. Similarly, the Gini-Simpson index and Effective number of species for the predatory fauna was derived as 0.898 and 9.804 , respectively. This interprets that the predatory arthropod community of flax has the same diversity as a community with $9.804 \approx 10$ equally-common species. So, the aboveground plant-dwelling pest and predator community of flax have more or less same diversity pattern as a community with 12 and 10 equally-common species, respectively.

\section{DISCUSSION}

Biodiversity is one of the primary interests of ecologists, but quantifying the species diversity of ecological communities is complicated. In addition to issues of statistical sampling, the rather arbitrary nature of delineating an ecological community and the difficulty of positively identifying all of the species present make it a challenging job to have a clear understanding of tritrophic interactions taking place in a specific agroecosystem. In the present study, there has been an attempt to have a clear understanding of the community structure of the pests and predators of flax ecosystem. In total, twenty five species of insect pests and sixteen species of predators have been found to occur on flax. Earlier, a number of researchers have tried to study the arthropod diversity in flax under varied agroclimatic conditions. Flax is cultivated for both seed (oilseed flax) and fibre (linen flax) $\left[{ }^{14}\right]$. The cultivars grown and the production practices used differ depending on the intended use of the flax crop. But there exists no difference in insect diversity between flax grown for seed or for fibre $\left[{ }^{15}\right]$.Twenty eight insect pests have been recorded in an overlapping manner on linseed under the agroclimatic condition of central Uttar Pradesh, India $[7]$. But Prasad and Prasad $\left[{ }^{8}\right]$ could record only twelve insect species to infest linseed in Jharkhand, India. Among the natural enemies of insect pests, spiders, black ants and rove beetle were noticed to be associated with the linseed agroecosystem. Deshmukh et al., $\left.{ }^{6}\right]$ recorded twenty one insect pests and one mite pest along with five natural enemies associated with insect pests of linseed at Delhi. Gavloski et al. $\left[{ }^{16}\right]$ tabulated twelve insect pests including root feeders, foliage and seed feeders and sap feeders to be most common insect species infesting flax in the Canadian prairies. These variations in the arthropod species diversity from the observations of our present study might be due to varied agroclimatic conditions as well as agroecological habitats of the locality in which the crop was grown.

The capsule borer, Helicoverpa armigera (Hubner) was observed as a major pest of flax during the present investigation. This observation draws support from the findings of Gavloski et al. $\left[{ }^{16}\right]$, Klein Koch and Waterhouse $\left[{ }^{17}\right]$, Prasad and Prasad $\left[{ }^{18}\right]$ and Deshmukh et al. $\left[{ }^{6}\right]$ who all recorded Helicoverpa spp. as an important pest of flax occurring in the different agroclimatic and ecological habitats all over the world. The shield bug, Plautia fimbriata (Fabricius) has been recorded for the first time as a major pest of flax from India. Earlier, it has been reported as a minor pest of pigeonpea, field bean, cowpea, cotton, and several other plants $\left[{ }^{19}\right]$. Linseed bud fly, Dasyneura lini (Barnes) has been reported as a key pest of flax from different parts of India $\left[{ }^{7,9,18}\right]$. But these observations are in contradiction with our present findings where it has been recorded as a minor pest in the hilly region of Eastern Himalaya of West Bengal, India. However, the results obtained conformed to the 
findings of Pathak $\left[{ }^{20}\right]$ who reported bud fly as a minor pest of linseed in all the states of North East India.

During the course of present study the spiders and lady bird beetles were emerged as the most dominant group of generalized predators in the flax ecosystems. These observations corroborate with the reports of Prasad and Prasad $\left[{ }^{8}\right]$ and Patel and Thakur $\left[{ }^{21}\right]$ who witnessed significant role of spiders (unidentified) and rove beetles (Paederus spp.) in reducing and checking the pest population build up in linseed. But contrary to these reports rove beetles could not be recovered from the flax ecosystem of Darjeeling hills during the present course of study.

\section{CONCLUSION}

The arthropod diversity was found to be quite rich in the flax agroecosystem under hilly terrain of Eastern Himalayas of Darjeeling, India. The diversity of herbivorous community marginally surpassed that of predatory community both in terms of GiniSimpson index and Effective number of species occurring in the flax ecosystem.

\section{CONFLICT OF INTERESTS}

The authors declare that there is no conflict of interests regarding the publication of this paper.

\section{REFERENCES}

1. Jhala AJ, Hall LM. Flax (Linum usitatissimum L.): Current Uses and Future Applications. Australian Journal of basic and Applied Sciences. 2010; 4: 4304-4312. 1

2. Millam S, Bohus O, Anna P. Plant cell and biotechnology studies in Linum usitatissimum -A review. Plant Cell Tissue Organ Culture. 2015; 82: 93-103. 2

3. Latif MA, Rahman MM, Islam MR, Nuruddin M M. Survey of arthropod biodiversity in the brinjal field. Journal of Entomology. 2009; 6(1): 28-34. 5

4. Weaver JC. Indicator species and scale of observation, Conservation Biology. 1995; 9: 939-942. 6

5. Jost L. Entropy and diversity. Oikos. 2006; 113: 363-375. 11

6. Deshmukh SD, Singh KM, Singh RN. Pest complex and their succession inlinseed, Linum usitatissimum L. Indian Journal of Entomology. 1992; 54: 168-173. 17

7. Malik YP. Insect-pests complex and their phenology in linseed, Linum usitatissimum in Central Uttar Pradesh. Indian Journal of Entomology. 1998; 60: 364-370. 18

8. Prasad R, Prasad D. Occurrence and succession of insect pests of linseed under agroclimatic conditions of Ranchi (Jharkhand). Indian Journal of Entomology. 2007; 69: 710. 19

9. Mishra MK, Ali S. Seasonal and varietal incidence of insect-pests of linseed. Indian Journal of Entomology. 2007; 69: 288-292.

\section{0}

10. Sirami C, Brotons L, Martin JL. Vegetation and songbird response to land abandonment: from landscape to census plot. Diversity and Distributions. 2007; 13: $42-$ 52. 21

11. Gangurde S. Aboveground arthropod pest and predator diversity in irrigated rice (Oryza sativa L.) production systems of the Philippines. Journal of Tropical Agriculture. 2007; 45: 1-8. $\quad 30$

12. Chakraborty A, Kumar K, Chitra N. Computation of insects biodiversity in Bhendi (Abelmoschus esculentus (L.) Moench) Ecosystem. The Bioscan. 2014; 9: 1405 1409. 31 
Arthropod diversity in Linum usitatissimum

13. Magurran AE. Measuring Biological Diversity. Blackwell Publishing, Oxford, UK. 200422

14. Johnston AM, Tanaka DL, Miller PR, Brandt SA, Neilsen DC, Lafond GP, Riveland NR. Oilseed crops for semiarid cropping systems in the northern Great Plains. Agronomy Journal. 2002; 94: 231-240.

15. Wise IL, Soroka JJ. Principal insect pests of flax. In Flax: The Genus Linum. Medicinal and Aromatic Plants - Industrial Profiles, Vol. 34. Edited by A.D. Muir and N.D. Westcott. Taylor and Francis, London, U.K. 2003. pp. 124-149. 24

16. Gavloski J, Cárcamo H, Dosdall L. Insects of Canola, Mustard, and Flax in Canadian Grasslands. In Arthropods of Canadian Grasslands (Volume 2): Inhabitants of a Changing Landscape. Edited by K. D. Floate. Biological Survey of Canada. pp. 181-214. 25

17. Klein Koch C, Waterhouse DF. 2000. The distribution and importance of arthropods associated with agriculture and forestry in Chile (Distribucion e importanciade los artropodos asociados a la agricultura y silvicultura en Chile). ACIAR Monograph No. 68, 2011. 234 pp. 26

18. Prasad R, Prasad D. Ecofriendly management of major insect pests of linseed. In: Proceedings of National Symposium of Frontier Areas of Entomological Research, held from 5-7 November, 2003 at IARI, New Delhi. 2003. pp. $326 . \quad 27$

19. $\quad$ http://www.nbair.res.in/insectpests/Plautia-crossota.php 32

20. Pathak KA. Insect pests of crops in North Eastern hills region of India and their management. In: Frontier Areas of Entomological Research (Eds. Subrahmanyam B, Ramamurthy VV, Singh VS.). Proceedings of the National Symposium on Frontier Areas of Entomological Research, IARI, New Delhi, India, Nov. 5-7, 2003 (Invited Lectures), 2004. pp. 93-130. 28

21. Patel RK, Thakur BS. Insect pest complex and seasonal incidence of linseed with particular reference to bud fly (Dasyneura lini Barnes). Journal of Plant Protection Environment. 2005; 2: 102-107. 